\title{
Rational and emotional tension balances in the organization of political hunger strikes.
}

\author{
CONNOLLY, J., DOLAN, P. and VERTIGANS, S.
}

2023

The final version of this paper has been published in Sociological Research Online, 28(1), March 2023 by SAGE Publications Ltd, All rights reserved. (C) The Author(s) 2021. It is available at:

http://journals.sagepub.com/home/sroa 


\title{
Rational and Emotional Tension Balances in the Organization of Political Hunger Strikes
}

Sociological Research Online 2023, Vol. 28(I) 3-20 (C) The Author(s) 2021

(c) (i)

Article reuse guidelines: sagepub.com/journals-permissions DOI: $10.1177 / 13607804211003592$ journals.sagepub.com/home/sro

\author{
John Connolly
}

Dublin City University, Ireland

\section{Paddy Dolan}

Technological University Dublin, Ireland

\section{Stephen Vertigans}

Robert Gordon University, Scotland

\begin{abstract}
This paper is concerned with the relationship between the organization of political hunger strikes, rational calculations and actions and emotions. Drawing from the theoretical formulations of Norbert Elias, we examine how rational-emotional balances generated by different and intertwined tiers of social integration partly shaped the organization of political hunger strikes. Political hunger strikes are interesting because they tend to involve actions based on rational considerations and emotional charges. The empirical context includes a comparative analysis across space and time involving the organization of political hunger strikes in Ireland and (West) Germany during the 20th century. Our analysis suggests a difference between the rationalemotional tension balance exhibited by hunger strikers of the $1920 \mathrm{~s}$ and that of hunger strikers of the 1970s and 1980s. We explain how these differences are connected to the broader social structures pertaining at the time. The main contention of the paper is that all forms of political organizing involve rational-emotional balances, and these balances are structured and shaped by social dynamics at different tiers of social integration.
\end{abstract}

\section{Keywords}

Elias, emotions, hunger strikes, organizing, rational

\section{Corresponding author:}

John Connolly, DCU Business School, Dublin City University, Collins Avenue, Dublin, 9, Ireland.

Email: John.connolly@dcu.ie 


\section{Introduction}

This paper examines the relationship between rational-emotional balances and the organizing of political hunger strikes within prisons. By political hunger strikes, we are referring to the actions of individuals comprising or allied to social groups which contest both the status conferred on them by the state and the state's wider activities (and in some cases the state's very legitimacy). In that sense hunger strike organization proceeds in relation to the practices, structures and ideologies of another organization - the state. Political hunger strikes are particularly interesting because they tend to involve actions based on rational considerations and emotional charges (Yuill, 2007). Drawing from the theoretical formulations of Norbert Elias (2012[1939]) we examine how rational-emotional balances generated by different and intertwined tiers of social integration partly shape the organization of political hunger strikes within prisons. The work of Elias has long been recognized by sociologists as relevant to the study of emotions (Burkitt, 1997; Kuzmics, 1991). Elias's approach is relational, and much of his work deals with changes in drives and emotional controls (external and internal), often captured within a broader movement between social and self-restraint, and their relationship to changing social interdependences. Emphasis on greater self-constraint underpins a greater capacity to think and act more rationally and forms one strand of his formulations on specific theoretical observations around rationalization processes.

Hunger strikes are a form of political resistance, generally involving the refusal to eat (and sometimes drink) as a means of protest to seek some form of change to a set of direct material conditions and/or wider socio-political objectives (Skleparis, 2017). They are also a form violence, violence against the self - one can physically harm or kill oneself. And, like war (Malešević, 2017), they always require some level of organization. The study of organization often involves a focus on rationalization. Indeed, as Courpasson and Reed (2004: 6) suggest, rationalization 'has been the compulsory point of departure for any analysis of modern organization in any kind of social context, whether it be the lecture theatre, the television studio or the democratic assembly'. At the same time, given the very nature of hunger striking - the risk of death, the physical and emotional pain - hunger strikes arouse considerable and varied emotional experiences for both hunger strikers themselves and many others. Yuill (2007) makes the observation that the 'actions of the Hunger Strikers could be seen as an example where both emotions and rationality work in tandem and are embodied in their actions'. The idea that thought and actions, rationally or emotionally derived, are not separate but connected and interdependent has currency within the sociological literature (Kuzmics, 1991). Even Weber, generally perceived as the primary sociologist of rationalization, was concerned with emotions (Albrow, 1992). Indeed both Weber and Elias conceive of rationality as referring to the calculation of the balance between short-term desires and emotional inclinations on the one hand, and the longer-term consequences of human action on the other. The more the balance is weighted towards the latter, the more rational are the actions (van Krieken, 2014). Because this shifting balance is integral to processes of organization, the isolation and separation of rationalization processes from emotions has been identified as deeply problematic in an empirical and theoretical sense (Barbalet, 2002). 
This brings us to an important contribution of our paper - to illustrate empirically how rational and emotional thoughts and actions are inseparable. That means that they should be understood, and treated, as relational social phenomena; one cannot understand the structure and nature of one without considering the other. Yet, studies continue to treat them as discrete phenomena. For instance, in their study of genocide, Stokes and Gabriel (2010: 476) claim that 'Modern genocides, as studied by historians, reveal themselves to be organized and managed ventures rather than spontaneous spasms of hatred'. This implies a separation between the rational and the emotional. Our study suggests, in support of Elias, that organizing involves rational-emotional balances and these balances are structured and shaped by social dynamics at different tiers of social integration.

The paper begins with an outline of Elias's formulations around the subject of rational-emotional balances. The next section concerns our methodological approach and the empirical settings. These relate to the organization of hunger strikes by members of militant republican organizations in Ireland ${ }^{1}$ and members of the Red Army Faction (RAF) in the former West Germany during the 20th century. As Wouters (1990: 706) suggests, explaining variations in collective and individual emotional developments demands an inquiry "into the ways in which "local" processes of emotional development and their result, the dominant emotional make-up or social habitus, can be understood, interpreted and explained by comparing their structural characteristics to those of other places and periods'. Consequently, the selection and analysis of data involved not just the 'localised' settings of hunger strikes but also data relating to dynamic social structures. We then present our data analysis which involves a synthesis of different levels of social integration before concluding with a discussion of our main arguments.

\section{Elias, rationalization, and emotions}

Elias saw rationalization processes as a narrow element within the broader dynamic of the self-control of emotions. For Elias (2012[1939]) rationalization is processual and part of a wider social process involving shifts in the balance between social and self-constraints, in the direction of the latter. It involves a greater (and more deeply ingrained) capacity for reflective hindsight, foresight, and calculation over longer and more complex chains of events. This relates to observation of oneself, others, and social situations more generally. While Elias does distinguish between self-restraint and rationalization (and other processes), they remain inseparable. Thus, in the hands of Elias, rationality is understood as being shaped relationally (through social interdependences at different levels of social integration) and is interconnected with a person's emotional controls and the ability to exercise a specific type and level of control of one's emotions. Consequently, those with the capacity for exercising more even and advanced levels of foresight and rationality simultaneously exert corresponding levels of self-control over their emotions. Interestingly, the fluidity (it is processual) in Elias's conception of rational-emotional balances does not negate the cementing of rational-emotion balances in the habitus; such balances do crystallize and take a specific form which is connected with the particular structure of society.

Elias's (2012[1939]) main contention is that rationalization is one manifestation of a wider process in which the balance between social and self-restraints shifts in the direction of the latter (he argues this became increasingly perceptible from the 16th century). 
In that sense, it is not possible to merely draw upon Elias's formulations on rationalization in isolation of his wider theory and related works. Elias explained through empirical-theoretical elaboration how the twin processes of expanding social differentiation, the social competition that drives and propels it further, and the formation of effective monopolies for the control of violence makes life in general more calculable while simultaneously generating a compulsion for exercising greater self-restraint. As the web of interdependences in which people are enmeshed expands and lengthens, people are required, in their efforts to navigate this social terrain successfully, to take those they are dependent upon into greater consideration - their needs, motivations, and demands. From this process of increasing social demands and pressures develops a more self-restrained, less emotionally volatile and more even habitus, in which the capacity for exercising greater self-control, foresight and calculation over longer chains of events becomes deeply anchored and second nature to the individual. The habit of a more steady and developed foresight is sustained and grows further with the increasing differentiation of social functions. This exercise of greater foresight over the actions and activities of others goes hand in hand with a process that Elias terms 'psychologisation' - a person's consideration of others is more nuanced and self-conscious, and they are more dispassionate in their responses to others. This also involves 'more precise observation of one self and others in terms of longer series of motives and causal connections' (Mennell, 1994: 186). And, as we stressed already, while Elias distinguishes between rationalization, psychologization, and greater self-control and foresight more generally, they remain in both an empirical and theoretical sense largely inseparable and interconnected. Consequently, if the pattern of self-control, which has become deeply anchored in individuals, advances further so too does their capacity for rationalization and psychologization.

In that sense, when we speak of rationalization or emotional responses we are never referring to one in isolation of the other; they are inseparable in terms of understanding the scale, structure and intensity of either. From an Eliasian perspective, whether one is examining emotional responses or rational calculations, one is invariably considering both simultaneously. Equally there is (and was) always a level of rationality involved in how people think and act, as there is too with control over spontaneous emotional responses; what differs over time and in societies and among different social groups is the relative rational-emotional tension balance (Newton, 1999).

At an individual level, this interweaving of emotions and rationality commences at an early age. Rationalization is partly learned; a child is socialized through their familial network and others to exert and value a particular form of foresight and calculation. This socialization reflects the social standards and expectations concerning rational thinking and foresight that have come to pertain at the time, or new standards coming to pertain. These standards are filtered through the wider development of the national we-group and one's social class. Middle-class groups are generally required to exert greater and more even levels of self-control which facilitate greater levels of calculative thought. It is imperative too to point out that Elias never suggested that such processes were linear or inevitable. Indeed, as both Elias and others (see van Krieken, 1999) illustrate, such a dynamic can run in parallel with counter processes involving schisms and reversals. Such counter processes are often noticeable during periods of heightened political 
tensions such as those that contributed to the adoption of hunger strikes as a tool to challenge power differentials.

\section{Data sources and methodological approach}

Our focus in this study is the organization of political hunger strikes within prisons. The later point of emphasis - 'within prisons' - is significant in that we were concerned only with the rational-emotional balances of hunger strikers or those imprisoned who were contemplating such action. As we indicated already, our empirical settings relate to Ireland (pre and post its partition in 1921) and the former West Germany. The number and scale of hunger strikes by militant groups differs significantly between Ireland and Germany over the course of the 20th century. Hunger strikes have been a constant feature in Irish society over the course of the 20th century in comparison with Germany (Passmore, 2011). Most of the hunger strikes in Ireland were initiated by Irish nationalists - those opposed to British state control or involvement in the governance of Ireland. A wide range of sources and material were available to us in respect of some of the Irish hunger strikes, including the prison diaries of hungers strikers, archived interviews with former hunger strikers, socio-historical monographs, and newspapers. The archived interviews of former hunger strikers form part of a large pool of almost 1,800 statements by Irish militant activists involved in what is known as the revolutionary period in Ireland (1913-1921), held by Bureau of Military History archives. These statements are based on interviews conducted in the 1940s and 1950s. Now digitalised, it meant we could use keyword searches such as 'hunger strike' to trawl through these statements. Two hunger strikers during that period, Frank Gallagher and Peadar O'Donnell, would later publish accounts of their experiences and these were analysed too. For the 1980 and 1981 hunger strikes, we relied mainly on historical monographs.

Our German case relates to the hunger strikes undertaken by members of the RAF. Here we relied heavily on the work of historian Leith Passmore. Passmore's (2011) work is based on material accessed at the Hamburg Institute for Social Research and the Federal archive in Germany. This included RAF texts, posters, material confiscated from their lawyers, writings found in their prison cells, police reports and trial transcripts. Passmore's meticulous detail and citing meant we were able to consider the provenance of the source including the author, where and when it was produced, its function and intended purpose, and the wider context in which it was written. This type of source appraisal is crucial within historical methodological approaches (Scott, 1990). Interestingly, in addition to drawing on Elias's theoretical contributions, we also critically examined his empirical data on members of the RAF. This appeared in his book Studies on the Germans, which although mainly directed at explaining the rise of the Nazis and the extermination of the Jews also examined the activities and membership of the extra-parliamentary groups (the RAF) of 1960s and 1970s West Germany.

As noted, in both the Irish and German cases, we relied on many secondary sources manuscripts written by historians and other social scientists. This mix of sources helps overcome some of the difficulties associated with reliance on a single piece of data as a source of facts. Our analysis was theory guided which aided interpretation and involved an analysis of individual strikes and time-periods followed by a comparative analysis 
across space and time. Interpretation of the data involved not just a consideration of multiple accounts (where possible) of the same event but a critical approach to the theory including an iterative process between theory and data in which the theoretical formulations are considered against the empirical evidence. This in turn enables greater trust the emerging synthesis.

Furthermore, as our analysis involved linking different levels of social integration, from lower to higher tier levels, we also required data beyond the context of specific hunger strikes and the organizations the prisoners comprised. For data on the changing social structures relating to Ireland we drew on the work of Dolan (2009a, 2009b) and Daly (2016). We supplemented this with further data - historical monographs and other studies particularly in relation to Northern Ireland. To examine the changing social structure in Germany we examined and drew from the works of Fulbrook (2015) and O'Dochartaigh (2004). Wouters' (2007) work provided a related and supporting synthesis on the changing social habitus of Germans in the 20th century.

\section{Analysis: prison hunger strikes and rational-emotional balances}

Beginning with data concerning hunger strikes that occurred in Ireland in the 1920s our analysis is organized and presented to illustrate comparative differences from temporal and national perspectives. Specifically these differences relate to variances in the rational-emotional balances of those involved in Irish hunger strikes in the 1920s and those involved in the strikes of the 1980s, as well as differences with those involved in German hunger strikes of the 1970s.

\section{The 1920s Irish hunger strikes}

Hunger striking re-emerged as a political and military tactic in Ireland in the early decades of the 20th century. The increasing militancy of the Irish nationalist movement from 1916 came to include hunger striking. The hunger strikes in 1917 occurred as the perceived legitimacy of British state control in Ireland weakened and the state's control of the monopoly of violence began to disintegrate (Lee, 1989). According to Stover (2014), by 1920 hunger striking had surpassed all other forms of prison protest ${ }^{2}$ in Ireland as the primarily means by which republican prisoners ${ }^{3}$ sought to oppose the prison authorities and the British state. Imprisoned Irish militants (now operating as the Irish Republican Army (IRA)) regularly raised the prospect of initiating hunger strikes. The following are some accounts to illustrate this:

After seven or eight days' hunger strike as a protest for political treatment, we were sent by boat from Cobh to Belfast. The weather was unduly bad for the month of March, spring tides prevailed, and one can realise the seasickness of eleven men who had been imprisoned for a considerable time.

After about a fortnight in Belfast, we again decided on hunger strike as the only weapon available, and we were then transferred to Mountjoy Prison, Dublin, . . . 
After some weeks, we decided finally we were going on hunger strike to get either political treatment or release. (Witness Statement 1348, Michael Davern, Bureau of Military History, p.31)

While the suggestion of going on hunger strike often appeared to be raised somewhat impulsively, the final decision was based on a level of calculation and analysis. For instance, in 1920 Irish republican prisoners held at Wormwood Scrubbs prison in England conducted a ballot on whether to hunger strike (Witness Statement 1393, Edmond McGrath, Bureau of Military History). One prisoner, Seán O'Carroll, recalled his experience of arriving at Wormwood Scrubbs. He noted that 100 prisoners were already on hunger strike and 60 others had refused to join:

Both sides put their case before us (the fifteen new arrivals). The hunger-strikers declared they had the approval of G.H.Q. for the strike, and the non-strikers maintained they had sent a special courier to Dublin and had been refused permission to strike. . . . After we had heard both of their stories we decided to adjourn and consider our own position.

We decided that, no matter who was right or who was wrong at the start, it was up to every man now to go on hunger-strike, and we appealed to the non-hungers to join in at once, and have a united front against the common enemy. (Witness Statement 1702, Seán O'Carroll, Bureau of Military History, p.14)

Similar levels of rational analysis are evident in the process around a suggested another hunger strike in 1923 during the Irish Civil War ${ }^{4}$. According to Healy (1982) the strike was initiated by a written message from the Director of Intelligence for the Republican forces, but the ultimate decision was left to the commanding officer in each prison, but in many cases it was 'democratically' decided by the prisoner groups themselves. Indeed, one prisoner recalled:

I called a meeting of the prisoners, informed them of the position, and pointed out to them that there was no suitable action we could take except to go on hunger-strike for political treatment. I was supported by the majority of the prisoners when the vote was taken. (Witness Statement 485, Brigid O’Mullane, Bureau of Military History, p.14)

Peadar O’Donnell (2013 [1932]: 152), who was also imprisoned at that time, notes in a diary that experienced hunger strikers were consulted in coming to the decision. We emphasize these examples to illustrate that while the idea to hunger strike may have been raised rather spontaneously and without significant levels of calculation, the final decision suggests that much greater levels of rational thought were brought to bear on the process. These calculations - the weighing up of outcomes, consideration of the experiences of those had previously gone on hunger strike, the willingness to debate the issues - were interwoven with strong emotive impulses and pulls. For instance, another prisoner at the time (1923), Joseph O'Connor, displayed considerable calculation (rational thinking) in initially opposing the strike. He reasoned that 'most of our men were more than a year locked up, not overfed, and their physical condition bad'. He also felt that the hunger strike 'for freedom was a spent force since Terry McSweeney's death (in 1920)'. This was indicative too of considerable reflection and hindsight. Yet, despite 
this 'rational' analysis, including consideration of what a strike might achieve and his resultant opposition to a strike, he still joined the strike because he 'couldn't stand by and let others fight for my freedom without standing by them' (Witness Statement 544, Joseph O'Connor, Bureau of Military History, p. 27). His reason illustrates just one of the emotional pulls that people also experienced in parallel with rational considerations. The emotional charges such as this, generated by different social interdependences and wefeelings, could lead to individual psychological conflicts. Guilt, shame and fear could interlope with hope, dreams and fantasy. The we-group of fellow prisoners, or even the wider group they comprised, the IRA, existed alongside other emotional charges generated by the we-image of the nation. Although there was a connection between these weimages - the we-feelings towards the IRA were partly generated by we-feelings towards the nation - they could also conflict with each other. For instance, during the 1920 hunger strike Frank Gallagher (1928: 79-80) documented his own torment over a request from a fellow prisoner, Brennan, who had seven children at home:

Brennan says he has fasted nine days . . . It is not his courage which is lacking. But he has seven kiddies . . . If he dies, they starve . . . 'My heart is torn out of me thinking of them', the letter says. 'The Doctor told me this morning that I cannot live without brandy. I would not ask it for myself. . . If you say no, I will not take anything' . . . My impulse was to let him decide for himself whether he should take anything or not . . . Then realized that, horrible though refusal was, this was the test case . . The answer, if other men's lives are to be saved must be, 'Take nothing'. . . . A bitter answer . . . Yet, how can it be otherwise? . . If this strike breaks, not ourselves alone, but Ireland is beaten . . . Men must die . . . But it is awful to have to kill men . . . to have to starve little children ...

The level of coordination within the various Irish hunger strikes of the 1920s was relatively rudimentary, hampered too on occasion by the large numbers involved and their disparate locations. For example, in the 1923 strike, which involved somewhere between 2,000 to 8,000 prisoners, the vast majority abandoned the strike within the first month (Healy, 1982; Sweeney, 1993). Prisoners started to come off the hunger strike after days, weeks and months but this was unplanned and uncoordinated (this, as will be illustrated later, is in contrast to the hunger strikes of the 1980s). Emotional impulses often took hold and were as much a basis for ending strikes as they were for starting them. O'Donnell (2013[1932]: 161) notes in his diary how stampedes took place in some prisons over food and the strike was called off altogether. Knowledge about hunger striking and its effects was relatively rudimentary. Scientific knowledge was interwoven with fantasy, often transmitted by gossip channels. One hunger striker from the 1920 s recalled that there was a rumour that after fifteen days on hunger strike, you lived off the marrow of your bones and you could end up a cripple as a result. He claimed that five to six hundred came off a strike because of this rumour alone (Witness Statement 1209, Stephen Keys, Bureau of Military History, p.40). Fears and fantasy shaped the scale of the strike in terms of numbers. This 'fantasy' knowledge of fasting can be contrasted with the knowledge available to RAF members on hunger strike in the 1970s, which we discuss later.

There were coordinating activities throughout the course of the various strikes at this time. In the 1923 strike messages were organized between the different prisons to garner the state of conditions and how individual strikes were holding within each prison. 
The cessation of the strikes also involved a level of calculation and coordination. For instance O'Donnell (2013[1932]: 178) recalls a meeting with other senior hunger strikers in their prison:

Tom Derrig, Frank Gallagher, Michael Kilroy and I were together at the final talk that decided that messengers from our jail should go to the other prisons and arrange that we all cease together. We should all cease otherwise Kilmainham [prison] could not come off, for most of those who had begun the strike were there.

The extent of the level of coordination and calculation really only becomes perceptible when compared against later strikes in Ireland (and Germany). Consequently, we now turn to the organization of hunger strikes in the 1980s, which occurred in the territory known as Northern Ireland.

\section{The 1980s Irish hunger strikes}

The 1980 hunger strike (the prelude to the now more infamous 1981 strike, in which 10 hunger strikers would die) was essentially an escalation of the prison protests known as the blanket and dirty protests ${ }^{5}$, which had been ongoing since the reintroduction of a criminalization policy by the British state in 1976 (Bishop and Mallie, 1988; O’Malley, 1990). Members of the Provisional IRA (PIRA) and another militant republican group, the Irish National Liberation Army (INLA), considered themselves, as did others, as prisoners-ofwar. Indeed, the British state had essentially perceived them as such prior to the mid-1970s with republican prisoners permitted to organize themselves within the prisons as military units with a related organizational and command type structure (Bishop and Mallie, 1988). The 1980 strike emanated from the perceived failure of the blanket and dirty protest to extract concessions from the British authorities and consideration of the options now left open - abandon, continue dirty protest, or elevate to the next level of protest. For instance, Brendan Hughes (a prisoner at the time) on hearing of the failure of negotiations with the British recalled: "I thought "Jesus, where do you go from here?" [. . .] I knew the only option left was hunger strike' (cited in Ross, 2011: 85). As with the 1920s strikes, there was both a rational and emotive aspect to the decision to go on strike. Yet, the planning and coordination of the strike indicates a far greater level of calculation and foresight than those organized in the 1920s. First, the timing of the strike was planned to ensure that the fast would peak at Christmas (O’Malley, 1990; Ross, 2011). This suggests that the prisoners had thought through the possible media coverage, imagery and emotional pangs, which could be generated by contrasting starving men on their deathbeds against the iconography associated with Christmas - feasts, indulgence and the espousal of peace and goodwill towards others. It is an example too of reflective hindsight and calculation.

The selection process was also indicative of this and involved far greater rational thought and relative bureaucratization in comparison to the 1920 s strikes. Unlike these strikes, which were generally open to anyone who wished to take part, the 1980 strike was restricted to seven. The reason for seven men $^{6}$ was to symbolically link with the seven signatories of the 1916 declaration of Irish independence (O’Malley, 1990). This was a calculated effort to not only create a symbolic link with the revolt by Irish militants in 1916, 
but also with the signatories who were subsequently executed by the British authorities. The extent of the calculation in the selection process can also be seen from the decision to select prisoners from five of the six counties under British jurisdiction so as to emotionally connect and mobilize as many nationalists as possible within those counties (Ross, 2011). Consideration was also given to the character of those to be chosen. This was partly based on how they had negotiated the prison conditions up to this point. All had to have demonstrated stamina and resilience during their part in the dirty protest and all were in leadership positions within the prison structure (O’Malley, 1990). A committee made up of the seven hunger strikers and 'block OC's [Officer Commanding-prisoner leaders] ${ }^{7}$ took decisions pertaining to the strike (O'Malley, 1990). There was also considerable coordination with outside support groups to mobilize public pressure and develop publicity campaigns.

The confused end of this strike and the sense of failure in achieving its purported aims, which many of the prisoners felt was the case (O'Malley, 1990), was the spur for the 1981 hunger strike. In that way, the impetus for this strike was driven less from rational calculation and more from an emotional charge generated by the sense of failure of the first strike, allied with the brutalizing effects of almost four years of blanket and dirty protests. While a level of emotional charge was an important impetus for the hunger strikes of the 1920 s and the 1980 strike, in this instance (1981 strike), the emotional charge was acutely strong. The leadership outside the prison was opposed to it mainly on the basis that they calculated it would fail. The then leader of Sinn Féin, the political wing of the PIRA, wrote to the prisoners stating, 'We are tactically, strategically, physically and morally opposed to the hunger strike' (cited in O'Malley, 1990: 72). The hunger strike was pushed by Bobby Sands who had been an OC involved in coordinating the previous 1980 hunger strike. O'Malley (1990: 72) suggests that there was 'no strategy - no clearly defined plan of how to proceed, no contingency arrangements, no back-up cover'. However, once some of the prisoners persisted with their intention to strike (which was also linked with inter-organizational competition between the PIRA and INLA) the level of rationalization and bureaucratization involved in organizing the strike grew. There was to be a gap between Sands (who would lead off the hunger strike) and the next hunger striker. This was to allow time for the British authorities to reflect on what to do before a second person would die. Initially only four were selected but a short list of potential follow-up strikers was drawn up (O'Malley, 1990). The subsequent death of Sands on hunger strike and the emotional charges generated by his death within the prison greatly re-shaped the strike's structure and organization. For instance, the Army council [leadership] of the PIRA instructed the strike be called off but this direct 'military order' was disobeyed by the next prisoner on strike (O’Malley, 1990), which essentially escalated the strike; emotional charges outweighed more rational considerations. However, greater levels of rational calculation would soon be deployed once the strike persisted. As more men put their names forward, criteria were developed for categorizing individuals acceptable or unacceptable for the strike. Consequently, those wishing to take part had to supply details of arrest, interrogation, and sentence. The nature of the offence for which a prisoner had been convicted was a major consideration in the selection process - some were immediately ruled out because of their offences - depending on the offence it would be easier to counter the portrayal by the British authorities and others 
that the strikers were criminals and murderers (O’Malley, 1990: 76). Selection for the short-list was also based on a number of further considerations such as ensuring a geographical spread by selecting prisoners from different counties. Prisoners with only short sentences remaining would not be shortlisted on the grounds that they would be more useful once released (O’Malley, 1990). This too had a bureaucratic structure in that the PIRA prison OC would select those to go on the list.

Once selected it was arranged that prisoners would join the strike at fixed intervals. Again, this is indicative of considerable hindsight, foresight, and calculation. Such a strategy involved knowledge and consideration of the effects on the physical and mental wellbeing of prisoners, the effects the hunger strike would have in generating public pressure and/or solidarity and the related pressure it could mount on the British government. However, interwoven with these rationalization processes were strong emotional impulses. More than any was the intense bonds that had fomented between the prisoners given the type of dependences between them and the longevity of these in many instances. The emotional charge generated by this superseded almost all others and this too shaped the organization of the hunger strike. It is particularly evident from their refusal to accept orders from the outside PIRA leadership. For instance, one prisoner, who was on hunger strike for 55 days, stated that it was the commitment and consideration of one's fellow prisoners and hunger strikers that overwhelmed all other considerations: "it would have taken more courage to actually stop of your own accord than to keep going on because it seemed so much like losing face ... and backing down when other men were dying' (cited in O’Malley, 1990: 85).

This is indicative of how rational-emotional considerations are so interwoven and inseparable and shape organizing. As the strikes continued and men began to die the emotional charges generated by this - loyalty to those that died, guilt, fear of failure, anger, and the desire not to concede - increasingly suppressed greater rational consideration of how effective the strike was in achieving some or all of the aims it was engineered to achieve. There was no agreement as to how long the hunger strike should last or how many should be allowed to die. Nor had the hunger strikers or wider body of prisoners considered or discussed in advance what they would accept as a settlement, what compromises if any they would tolerate and accede to (O'Malley, 1990). It would appear that many persisted (to their deaths in several cases) with the hunger strike because of the emotional charges generated by these intra-prison interdependences. Elias's (2007[1983]) concepts of involvement and detachment are also insightful here in understanding how one's 'involvement' can enhance and drive emotional charges that act against a more 'detached' analysis of social situations. As Elias explained in a 1981 lecture (see Elias, 2008: 138), it is enormously difficult for people to extricate themselves from a situation in which they can 'not master dangers because of the affectivity and the fantasy content of their thinking, and in which the great dangers themselves caused the high level of fantasy and emotionality in thinking'.

\section{The 1970s RAF hunger strikes in West Germany}

Like the 1980s Irish hunger strikes, the RAF hunger strikes in the 1970s in West Germany suggest more advanced levels of bureaucratization relative to the Irish strikes of the 1920s. 
The organization of the strikes was largely driven by calculations and consideration of their publicity and media effects. For instance, during the first hunger strike in 1973 Andreas Baader, who had begun the strike, stopped the strike 'because nothing of any significance is afoot outside anymore' (cited in Passmore, 2011: 62). Similarly, the second hunger strike (again in 1973) ended when media interest was deemed to have faded (Passmore, 2011). It would also appear that significant consideration was given to understanding the physical and medical process of fasting by prisoners. For instance, during the second RAF hunger strike a manual for starvation was found in Ulrike Meinhof's (one of the RAF leaders) prison cell:

The five-page document described the symptoms associated with self-starvation, providing the ideal weight loss, and even outlined the critical phases of the body's deterioration: pulse less than sixty or fifty, blood protein level of between 3 and 5 percent, a shift in the $\mathrm{pH}$ of the blood. (Passmore, 2011: 62)

This is indicative of considerable rational thought being brought to bear on the process; scientific knowledge is sought and possibly drawn upon to facilitate or inform a hunger strike. This type of calculative approach to the hunger strikes can also be seen in other organizational aspects of the third hunger strike (in 1974). Prisoners (hunger strikers) stored food and ate at specific times, if necessary, so as to prolong their strike (Passmore, 2011), as a strategy. Eating was used to control the rate of deterioration so that prisoners would come closer to the risk of death at different periods thus generating more sustained and heightened media coverage. Undoubtedly, the hunger strike strategy was partly linked to publicity generation due to the careers of several of the leading activists, such as the former journalist Ulrike Meinhof.

It would seem there was considerable reflection and contemplation on the process of hunger striking. In communications and writings within the prison, designed for fellow RAF prisoners, members of the RAF ruminated on what would or might be necessary in organizing further hunger strikes - would death be required for example. They also alluded to and drew upon narratives associated with the IRA hunger strikes of the 1970s (Passmore, 2011). These appeared to serve the function of illustrating the effectiveness of such a strategy and bringing heroic status to an activity which had a more familiar and mythical status in Ireland than in Germany. They actively attempted to orchestrate the dissemination of a specific discourse through which a specific image of hunger striking would be constructed and choreographed. However, the function of the strikes was also to generate a discourse through which the significance and meaning of the RAF could be sustained and made tangible to a wider audience. This approach was no mere side effect or unplanned consequence of the strike but a conscious and deliberate decision and strategy. What it demonstrates also is the intellectual thinking directed at the concept of hunger striking as well as consideration and calculation of its possible effects.

There were also class differences between 1970s German hunger strikers, who were mainly middle class (Elias, 2013[1989]; Varon, 2004; Vertigans, 2011, 2016), and the 1980s Irish hunger strikers who were predominately working class or lower middle class. This aspect is an interrelated aspect too of the different rational-emotional balances and 
layers of constraints associated with each group. The RAF hunger strikes involved a greater element of intellectualization in that the actual practice of hunger striking (and violence more generally) receives more abstract discussion and conscious reasoning connected to discursive and communicative objectives (Varon, 2004). It would seem that there is greater conscious reflection on the tactic. Indeed this mirrors what Elias (2013[1989]) analysed and suggested in relation to the RAF and their use of physical violence more generally, which he argued required, to a considerable extent, 'justification through reflection, legitimisation through a theory' (p.335).

\section{Social structures, rational-emotional balances and organizing}

Our primary contention is that there are variations in the rational-emotional tension balance exhibited by 1920s Irish hunger strikers and those of the 1980s Irish strikers and the 1970s German hunger strikes. And these differences in the rational-emotional balances partly shaped the organization of the different hunger strikes. We stress that this involves differences in the relative balance between spontaneous emotional actions and rational considerations. In this section we explain how these differences are connected to the broader structures of society (social structures) pertaining at the time. Elias (2012[1939]: 450) maintains that rationalization is not solely about changes in ideology or in a person's knowledge. It involves structural changes in the social habitus of people. The driver of this process is a transformation in the way in which people are bonded to each other - the structure of social interdependences. Consequently, our focus here is the social structures that pertained in Ireland in the 1920s and 1980s (and in West Germany in the 1970s). Beginning with Ireland, and covering the period from the early 1900 s to the 1980 s (the Irish Free State from 1921, later known as the Republic of Ireland from1949), our analysis indicates that the division of functions and chains of interdependences within which people were enmeshed became far more extensive and longer. Processes of commercialization, international trade, industrialization, urbanization, and secularization expanded significantly over this period in tandem with an expansion of state functions. These processes also contributed to a restructuring of power ratios; mainly a lessening of power imbalances between different social groups and categories - social classes, genders, parents-children, employersworkers, church-state. These were not linear developments, but uneven and contradictory at times. Nonetheless, they occurred within a broader development of expanding and social interdependences which generated more diverse social pressures on all people (Dolan, 2009a, 2009b) We stress this because, as Elias explains, more reflective, long-sighted and calculative capacities within the habitus only develop within a social structure where advancing functional differentiation and the related expansion in social interdependences continually demand them. This expansion in social interdependences in the Republic of Ireland ran in parallel with a process of growing state-legitimacy and a state monopoly for the control of violence. However, both these developments were fragile due to the Irish state formation process. According to Elias (2013[1989]) the successes and failures of the nation can become deeply sedimented in the national habitus of a people. The partial success of national liberation 
through violence along with the realization that a large group of nationalist minded people were 'left behind' generated a deeply ingrained guilt (for many who had attained Irish independence) as did the inability to address it. This in turn contributed to the lack of perceived legitimacy of the Northern Ireland 'State' among many Irish people, though to varying degrees. It also sustained a level of ambivalence to the use of violence there, and in Britain, by Irish militant groups seeking re-unification.

In Northern Ireland (from 1921) these processes were even more fractured - the legitimacy of this social unit, and the state monopoly for the control of violence linked with it, were not only weakly accepted by many but also contested. Groups seeking different state structures following partition continued to use violence to this end. Although this type of violent activity persisted through the decades, it escalated considerably in the 1970s. Nonetheless, processes reflecting expanding social interdependences did occur between the 1920s and 1980s; agricultural employment declined significantly over this period replaced mainly by employment in services (Simpson, 1975/1976), while state services also expanded (Rowthorn, 1981). Agricultural employment, which accounted for $25 \%$ of the labour force in 1945 , was $10 \%$ by 1970 (Rowthorn, 1981: 5). This changing structure involves, as Rowthorn (1981: 12) acknowledges, a move 'away from traditional manual skills learned on the job, towards skills acquired through formal learning in the educational system' and 'a shift from male to female labour'. This in turn demanded and impelled new and different personal and social skills to navigate this more complex network of social interdependences. Although employment and other social opportunities were still strongly related to ethnic affiliation (Rowthorn, 1981), this began to weaken somewhat (it did not disappear) by the 1960s. Expanded educational opportunities and a rise in the power chances of nationalists and Catholics would contribute to this dynamic. Initially too, it led to a heightening of ethnic tensions and hostility in the late 1960s, which in turn were a contributing process in the social climate from which the 1980s hunger strikes would emerge. Overall, though, it also reflected a move in the direction of less uneven power-balances between nationalists and unionists.

While there were differences in the extent and type of social independences in the Republic of Ireland and Northern Ireland, overall from the 1920s through to the 1980s, people in both jurisdictions, of different classes, genders, and ethnic identification came under increased social pressure to exert a greater level of self-restraint demanded by the changing structure of power relations. With this more self-restrained habitus comes the capacity for greater foresight, rational thought and action. It is this development, which partly explains the structural variation in the rational-emotional balance of the 1920s hunger strikers and the 1980s hunger strikers. By partly, we mean other social processes involving other tiers of social integration - families, the prisons, the militant organizations the hunger strikers were part of - all served to intertwine and shape the organization of the hunger strikes.

West Germany too underwent a transformation, becoming more structurally complex and expansive in terms of the broad network of social interdependence. Not only did the population expand (from 43 million in $1939^{8}$ to 61.7 million by 1980), it also became more urbanized. In 1950, $29 \%$ of the West German population lived in communities of less than two thousand inhabitants. By 1980 only $6 \%$ lived in such 
communities; instead 74\% lived in communities of over 10,000 (Fulbrook, 2015). This ran in tandem with a change in the structure of employment - away from agriculture and manual employment towards 'white-collar' occupations. The 'social market' version of capitalism that emerged in the 1950s also contributed to more even power relations between workers and employers (O'Dochartaigh, 2004). Combined with a reduction in the power differentials between the social classes, generations, and genders, which were connected with the changes just referred to, more social groups of all types were compelled to exerted greater levels of self-restraint in their relations with others. Wouters' (2007) work would support our overall contentions in relation to both the broader network of interdependences, changing power relations and the development of a more self-restrained and more rational social habitus. And while Wouters does not document specific changes in rationalization processes, he does illustrate the changes in relation to more advanced levels of self-regulation, which as we have suggested earlier both reflects and demands a capacity for reflective hindsight and foresight over longer chains of events. Our analyses of the RAF hunger strikes suggest considerable levels of rationalization were brought to bear on their organization, certainly relative to those organized in Ireland in the 1920s. We suggest too, somewhat contingently, that there are differences between the rational-emotional balances of those involved in the 1980s Irish hunger strikes and those partaking in the 1970s German hunger strikes, with the latter betraying more advanced levels of rationalization.

\section{Conclusion}

This paper's primary aim was to explain differences in the organization of political hunger strikes by considering the relationship between historical variances in the rational-emotional balances of people and social structures by drawing on the theoretical formulations developed by Elias. We illustrate empirically how rational-emotional balances and related organizing are shaped by interweaving and conflicting social processes at different tiers of social integration. Expanding and lengthening chains of social interdependences and more equal power relations occurring at higher tier levels of social integration, which impelled greater rationalization, also ran in tandem with other (sometimes) conflicting social processes which pushed against this. These included emotional bonds generated by face-to-face relationships, perceptions of state legitimacy, the form of state formation and the role of violence in this, and continued intra-state violence.

Finally, we would like to reiterate, and as this study shows, rational and emotional thinking and behaviour are inseparable. Consequently, it is the changing balance and structure of the rational-emotional relationship, and why and how this changes, that should be the focus of social inquiry.

\section{Funding}

The author(s) received no financial support for the research, authorship, and/or publication of this article. 


\section{Notes}

1. The terms Ireland and Germany refer to various states connected with these territories over the course of the 20th century. Ireland refers to the country under the jurisdiction of British governments up to 1921 when it was partitioned. This led to an independent Irish State, which would become known as the Republic of Ireland from 1949 and a self-governing territory known as Northern Ireland, which became part of the United Kingdom of Great Britain and Northern Ireland. Germany refers to the nation up to 1945. Two states emerged post 1945 when it too was partitioned into what became known as East and West Germany or the German Democratic Republic and Federal Republic of Germany respectively.

2. Refusal to obey the prison authorities, destruction of prison property and physical attacks on prison warders were the other forms of protest undertaken.

3. Many Irish nationalists began to self-identify as Republicans for they sought independent self-government in the form of a Republic.

4. This strike was actioned as a means to pressurize the Irish Free State government to release anti-treaty prisoners.

5. The blanket protest refers to the refusal of Republican prisoners in Northern Ireland to wear prison clothes in response to the British government's criminalization policy in 1970s. This escalated into the dirty protest when the prisoners refused to 'slop-out' (O'Malley, 1990).

6. Six were members of the IRA and one INLA member.

7. OC refers to officer commanding as in a conventional military unit. The PIRA organized as a military unit within the prison with each prison block having a commander. The physical structure of the prison resembled a series of $\mathrm{H}$-shaped structures which lead to the label 'H-Blocks' (Bishop and Mallie, 1988).

8. This refers to the territory that would become West Germany.

\section{References}

Albrow M (1992) Sine Ira et Studio - or Do Organizations Have Feelings? Organization Studies 13: 313-329.

Barbalet J (2002) Introduction: Why emotions are crucial. The Sociological Review 50: 1-9.

Bishop P and Mallie E (1988) The Provisional IRA. London: Corgi Books.

Burkitt I (1997) Social relationships and emotions. Sociology 31: 37-55.

Courpasson D and Reed M (2004) Introduction: Bureaucracy in the age of enterprise. Organization 11: $5-12$.

Daly M (2016) Sixties Ireland: Reshaping the Economy. State and Society, 1957-1973. Cambridge: Cambridge University Press

Dolan P (2009a) Developing consumer subjectivity in Ireland: 1900-1980. Journal of Consumer Culture 9: 117-141.

Dolan P (2009b) Figurational dynamics and parliamentary discourses of living standards in Ireland. British Journal of Sociology 60: 721-739.

Elias N (2007[1983]) Involvement and Detachment. Dublin: University College Dublin Press.

Elias N (2008) Power and civilisation. Journal of Power 12: 135-142.

Elias N (2012[1939]) On the Process of Civilisation: Sociogentic and Psychogenetic Investigations. Dublin: University College Dublin Press.

Elias N (2013[1989]) Studies on the Germans. Dublin: University College Dublin Press.

Fulbrook M (2015) A History of Germany 1918-2014. Chichester: Wiley Blackwell.

Gallagher F (1928) Days of Fear. London: John Murray.

Healy J (1982) The Civil war hunger-strike: October 1923. An Irish Quarterly Review 71: 213-226. 
Kuzmics H (1991) Embarrassment and civilization: On some similarities and differences in the work of Goffman and Elias. Theory, Culture \& Society 8: 1-30.

Lee J (1989) Ireland, 1912-1985. Cambridge: Cambridge University Press.

Malešević S (2017) The organisation of military violence in the 21st century. Organization 24: 456-474.

Mennell S (1994) The formation of we-images: A process theory. In: Calhoun C (ed.) Social Theory and the Politics of Identity. Oxford: Blackwell, pp. 175-197.

Newton T (1999) Power, subjectivity and British industrial and organizational sociology: The relevance of the work of Norbert Elias. Sociology 33: 411-440.

O’Dochartaigh P (2004) Germany since 1945. New York: Palgrave.

O'Donnell P (2013[1932]) The Gates Flew Open. Cork: Cork Mercier Press.

O'Malley P (1990) Biting at the Grave. the Irish Hunger Strikes and the Politics of Despair. Belfast: Blackstaff Press.

Passmore L (2011) Ulrike Meinhof and the Red Army Faction. New York: Palgrave Macmillan.

Ross SF (2011) Smashing H-block. Liverpool: Liverpool University Press.

Rowthorn B (1981) Northern Ireland: An economy in crisis. Cambridge Journal of Economics 5: $1-31$.

Scott J (1990) A Matter of Record: Documentary Sources in Social Research. Oxford: Blackwell. Simpson JV (1975/1976) Population, employment and urbanisation trends in Northern Ireland. Journal of the Statistical and Social Inquiry Society of Ireland XXIII: 120-134.

Skleparis D (2017) The politics of migrant resistance amid the Greek economic crisis. International Political Sociology 11: 113-129.

Stokes P and Gabriel Y (2010) Engaging with Genocide: The challenge for organization and management studies. Organization 17: 461-480.

Stover JD (2014) Irish political prisoner culture, 1916-1923. Crosscurrents 64: 90-106.

Sweeney G (1993) Irish Hunger Strikes and the Cult of Self-Sacrifice. Journal of Contemporary History 28: 421-437.

van Krieken R (1999) The barbarism of civilization: Cultural genocide and the 'stolen generations'. British Journal of Sociology 50: 297-315.

van Krieken R (2014) Norbert Elias and emotions in history. In: Lemmings D and Brooks A (eds) Emotions and Social Change. Historical and Sociological Perspectives. New York: Routledge, pp. 19-42.

Varon J (2004) Bringing the War Home: The Weather Underground, the Red Army Faction, and the Revolutionary Violence in the Sixties and Seventies. Berkeley: University of California Press.

Vertigans S (2011) Sociology of Terrorism: Peoples, Places and Processes. Abingdon: Routledge. Vertigans S (2016[2008]) Terrorism and Societies. Aldershot: Ashgate.

Wouters C (1990) Book review. The Social Construction of Emotions, edited by Rom Harré. Theory, Culture \& Society 6: 704-707.

Wouters C (2007) Informalization. Manners \& Emotions since 1890. London: SAGE.

Yuill C (2007) The body as weapon: Bobby sands and the republican hunger strikes. Sociological Research Online 12: 111-121.

\section{Author biographies}

John Connolly is a Senior Lecturer at Dublin City University. His research interests include figurational approaches to sport, organizations, and generational tensions. His work has been published in The Sociological Review, Sociology, Organization, and Theory, Culture \& Society, among others. He is co-author (with Paddy Dolan) of Gaelic Games in Society: Civilizing Processes, Players, Administrators and Spectators (Palgrave, 2020). 
Paddy Dolan is a Senior Lecturer in Sociology at Technological University Dublin. His research interests include figurational sociology, sport, childhood, emotions, organizational change and social identities. He is co-author (with John Connolly) of Gaelic Games in Society: Civilizing Processes, Players, Administrators and Spectators (Palgrave, 2020), and his work has been published in Sociology, British Journal of Sociology, Sociological Review, History of Education, and Media, Culture \& Society, among others.

Stephen Vertigans is a sociologist who is currently Head of School of Applied Social Studies at Robert Gordon University, Aberdeen, UK. His research interests include political violence, informal settlements and corporate social responsibility.

Date submitted 28 July 2020

Date accepted 24 February 2021 